\title{
Associations between herd-level feeding management practices, feed sorting, and milk production in freestall dairy farms
}

\author{
A. D. Sova, ${ }^{*}$ S. J. LeBlanc, $†$ B. W. McBride, $\ddagger$ and T. J. DeVries*1 \\ *Department of Animal and Poultry Science, University of Guelph, Kemptville Campus, 830 Prescott Street, Kemptville, Canada K0G 1J0 \\ †Department of Population Medicine, and \\ łDepartment of Animal and Poultry Science, University of Guelph, 50 Stone Road E., Guelph, N1G 2W1, Canada
}

\begin{abstract}
The challenges associated with group-housed dairy cows include within-herd variability in nutrient consumption and milk production, which may be related to feeding management. The objective of this observational study was to examine the association of herdlevel feeding management factors, feed sorting, and milk production. Twenty-two freestall herds with an average lactating herd size of $162 \pm 118$ cows, feeding total mixed rations, were each studied for 7 consecutive days in summer and winter. In cases of multiple feeding groups within a herd, the highest producing group of cows with an even distribution of days in milk and parity was selected for this study. The average group size studied was $83 \pm 31$ cows. The average study group consisted of cows $187 \pm 47$ days in milk, with a parity of $2.3 \pm 0.6$, consuming $24.3 \pm 2.6 \mathrm{~kg}$ of dry matter, with an average group-level yield of $34.3 \pm 6 \mathrm{~kg}$ of milk/d, $3.7 \pm 0.3 \%$ milk fat, and $3.2 \pm 0.18 \%$ milk protein. Milk production parameters, including yield, fat, and protein, were recorded through regular Dairy Herd Improvement milk testing. A survey of feeding management practices and barn characteristics was administered on each farm. The amounts of feed offered and refused were recorded and sampled daily to assess dry matter intake (DMI) and particle size distribution. Feeding twice per day compared with once per day was associated with an average increase of $1.42 \mathrm{~kg}$ of DMI, $2.0 \mathrm{~kg}$ of milk yield, and less sorting against long ration particles $(>19 \mathrm{~mm})$. Every $2 \%$ group-level selective refusal (sorting) of long particles was associated with $1 \mathrm{~kg} / \mathrm{d}$ of reduction in milk yield. A $10 \mathrm{~cm} /$ cow increase in feed bunk space was associated with a 0.06-percentage-point increase in group-average milk fat and a $13 \%$ decrease in group-average somatic cell count. These results support that herd-level management practices to promote feed access, such as increased
\end{abstract}

Received February 8, 2013.

Accepted March 15, 2013.

${ }^{1}$ Corresponding author: tdevries@uoguelph.ca feeding frequency and bunk space, may improve DMI and promote more balanced nutrient intake and greater milk production.

Key words: feeding management, sorting, milk production

\section{INTRODUCTION}

The efficiency of nutrient conversion to milk components substantially influences the profitability of a dairy herd. Costs associated with feed are continually rising and, on average, can account for greater than $50 \%$ of all operating costs of dairy production systems (USDA-ERS, 2013). As a result, producers have adopted the use of TMR delivery as a means of reducing labor costs and ensuring that a homogeneous supply of nutrients is delivered to the rumen for optimal digestive function (Coppock et al., 1981). Though this method of feed delivery should theoretically ensure consumption of a balanced ration, cows have been shown to sort the ration such that nutrient intakes are variable both day-to-day and between cows within a pen (Leonardi and Armentano, 2003; DeVries et al., 2008).

Several lines of evidence exist to suggest that herdlevel feeding management factors can decrease feed sorting and improve bunk access, thus reducing variability in nutrient intake across the herd. Feed bunk attendance is observed to be highest following practices that increase feed availability, such as feed delivery and feed push-up (DeVries et al., 2003), but most notably by delivery of fresh feed (DeVries and von Keyserlingk, 2005). Further, it has been shown that increasing the frequency of feed delivery from once to twice daily reduced TMR sorting and resulted in more equal bunk access for all cows, especially in the peak hour following feed delivery (DeVries et al., 2005). Competition for feed bunk access may also affect feeding behavior and access to a consistent ration. Huzzey et al. (2006) reported decreased displacements at the feed bunk, especially for subordinate cows, as a result of increasing feed bunk space per cow. In the same study, Huzzey et al. (2006) reported favorable decreases in displacements of subordinate cows from the bunk when headlock feed- 
ers were used, suggesting that feed bunk design affects success at the feed bunk. Competition at the feed bunk can alter feeding patterns and meal characteristics observed between dominant and subordinate cows and, as a result, negatively affect the consistency of the ration consumed within the group (Hosseinkhani et al., 2008). Excessive sorting of the ration, as well as exposure to an inconsistent ration, can lead to depressed rumen $\mathrm{pH}$ and an increased risk of ruminal acidosis (DeVries et al., 2008).

The vast majority of research in the area of feed sorting and feeding behavior has been in controlled experiments. Though this research has been central to understanding the relationship between feeding behavior and feeding management practices, a paucity of data exists on how these practices influence productivity at a herd level under commercial settings. Herdlevel feeding practices, such as an increased frequency of feed delivery, reduce the extent of change in ration NDF throughout the day (Endres and Espejo, 2010). Furthermore, Bach et al. (2008) reported that 50\% of the variability in milk yield of herds fed an identical ration were attributed to differences in nondietary factors, such as stall density and feed push-up. The results of these previous 2 studies illustrate the importance of feeding management factors as they relate to variability in intake and milk production, but these studies have limitations. Endres and Espejo (2010) were limited to using the change in NDF as a proxy for determining feed sorting, rather than evaluating changes in the consumption of different ration particles. Furthermore, those researchers limited their data collection to a single day of data per herd. Bach et al. (2008) enrolled farms that fed an identical ration, so conditions in that study may not have reflected the typical variability in nutritional programs that occurs between commercial farms. Thus, the objectives of this cross-sectional observational study were (1) to describe the feeding, housing, and management practices on commercial freestall herds and (2) to examine the associations between herd-level feeding, housing, and management practices, and measures of feed sorting and productivity. We hypothesized that herds with improved feed access, including increased feed bunk space, frequency of feed delivery, and feed push-up, would have greater group-average milk production parameters and exhibit less sorting behavior at the group level.

\section{MATERIALS AND METHODS}

\section{Farm Selection}

Twenty-four commercial dairy farms in eastern Ontario, Canada, were recruited for participation in this study. Sample size was determined through power analysis using the Power Analysis and Sample Size software program (PASS, Kaysville, UT; Hintze, 2008). Estimates of variation for the primary response and dependent variables (including DMI, milk production, efficiency of milk production, and feed sorting) were based on previously reported values (average $\mathrm{CV}=$ $12 \%$ ) from similar herd-level studies (Britt et al., 2003; Endres and Espejo, 2010) and group-level estimates of feed sorting (Leonardi and Armentano, 2007). An estimated sample size of 24 herds was determined sufficient to detect a prevalence of $10 \%$ greater production (as well as DMI, efficiency, and sorting) with $95 \%$ confidence. A list of prospective producers was identified by CanWest DHI (Guelph, Canada) based on a herd size greater than 50 cows, primarily Holstein genetics, freestall housing, and geographic location (within 150 $\mathrm{km}$ of Kemptville, Canada). Initial questionnaires to assess suitability for participation were prepared and mailed by CanWest DHI to those prospective producers. Farms were enrolled through a combination of mail and telephone contact. Farms meeting the previous criteria and expressing willingness to participate were enrolled. Ten farms were enrolled through mail and an additional 14 through telephone. One farm withdrew from the study during the first data collection period due to time commitments. One farm was included in the study but excluded from statistical analysis, as sampling and recording protocols were not met. Thus, data from 22 herds were included in this study and its analysis.

Participating farms were visited for 7 consecutive days in both summer (June-September) and winter (December-March) periods. Distribution of data collection was split over 2 summers. Nine farms were studied in the summer of 2011 and the remaining 13 were studied in the summer of 2012. All 22 farms were visited in 1 winter period (December 2011-March 2012).

\section{Within-Herd Group Selection}

Data collection was limited to 1 focal pen per farm. In cases where multiple cow groups existed, the highest producing group with an even distribution of DIM and parity and a size of greater than 50 cows (or $>40 \%$ of the total lactating herd population) was selected for study. Effort was made to exclude groups consisting primarily of fresh cows and first lactation cows.

\section{Cow Measures}

The timing of data collection during each summer and winter period was scheduled to coincide with a regular DHI milk test date $( \pm 3 \mathrm{~d})$. The DHI records 
from the coinciding test date were accessed to acquire milk production data, including milk yield, fat, protein, MUN, and SCC, as well as cow characteristics including DIM and parity. Data were collected only for those cows in the focal group in each herd. For each cow, using DHI data, 4\% FCM was calculated as follows: $4 \% \mathrm{FCM}=(0.4 \times$ test-day milk yield $)+(15.0 \times$ fat yield) (NRC, 2001). Similarly, ECM was calculated for each cow as follows: $\mathrm{ECM}=(0.327 \times$ test-day milk yield $)+(12.95 \times \mathrm{kg}$ of milk fat $)+(7.2 \times \mathrm{kg}$ of milk protein) (Tyrrell and Reid, 1965). Body condition score was evaluated for all cows in the focal group during both 7-d data collection periods and was based on a 5-point scale (Wildman et al., 1982). Cows were scored by 2 individuals and averaged to obtain 1 BCS per cow per period. Inter- and intraobserver reliability was established before scoring to ensure validity of results by calculating the correlation coefficient between different days of validation scoring. Average Pearson correlation coefficients for each observer were 0.89 and 0.83 , and between observers was 0.84 .

\section{Housing and Feeding Management}

Information on housing, milking, and feeding management was obtained through a questionnaire administered to the herd manager during the first week of data collection. The questionnaire covered aspects of ration formulation, stall management, milking, and feeding practices. Producers kept a daily log of timing of milking, feed delivery, and feed push-up. Linear bunk and water trough measurements were recorded by researchers. Pen group population size was recorded daily to calculate daily feed bunk space, water trough space, and stall stocking density. Minimum, maximum, and average barn temperature and humidity were recorded daily in the focal pen using a hygrometer (BIOS, Thermor Ltd., Newmarket Ontario, Canada) in each 7-d observation period.

\section{Feed Sampling and Analysis}

Farms were visited daily during each 7-d observation period at the time of first feed delivery. Amount of feed offered, based on the amount dispensed to each group by a TMR mixer wagon, was recorded daily at the time of feeding. This was calculated by recording the initial scale weight on the TMR mixer and subtracting any balance after feed was delivered to the focal group. Additional feeding events, including timing and amount, were recorded by the farm manager. Daily feed refusal amount was recorded $24 \mathrm{~h}$ after delivery of the first feeding event using a portable scale (Ohaus ES50R, Dundas, Ontario, Canada). Daily DM offered and refused were calculated by multiplying the daily as-fed amount of TMR offered and refused by the DM percentage of that feed (as determined through daily samples taken of that offered and refused feed), respectively. Daily pen-level DMI was recorded by subtracting DM refused from total DM offered.

Samples of the fresh and refusal TMR, respectively, were taken at the time of delivery and 24 -h postdelivery. Duplicate samples were collected at these times to assess particle size and the DM or chemical content of the ration. Fresh feed was sampled from 5 different areas of the feed bunk, at the beginning, middle, and end of TMR delivery, and within minutes of delivery to ensure accurate representation of the TMR. Refusals were sampled subsequent to bunk clean-up and were mixed to obtain a representative sample. All samples were frozen at $-20^{\circ} \mathrm{C}$ until processing.

Samples for particle size separation were thawed and separated using the 3 -screen $(19,8$, and $1.18 \mathrm{~mm})$ Penn State Particle Separator (PSPS; Kononoff et al., 2003). This separated the particles into 4 fractions: long $(>19$ $\mathrm{mm})$, medium $(<19$ and $>8 \mathrm{~mm})$, short $(<8$ and $>1.18$ $\mathrm{mm})$, and fine $(<1.18 \mathrm{~mm})$ particles. After separation, the DM of each separated fraction was determined by oven-drying at $55^{\circ} \mathrm{C}$ for $48 \mathrm{~h}$. Particle size distribution (\%) was calculated on a DM basis by dividing each dried fraction weight by the total dried sample weight. Samples taken for DM and chemical analysis were ovendried at $55^{\circ} \mathrm{C}$ for $48 \mathrm{~h}$ and then ground to pass through a 1-mm screen (Brinkmann Mill, Brinkmann Instruments Co., Westbury, NY). Both fresh DM samples plus the dried TMR particle fractions, were sent to Cumberland Valley Analytical Services Inc. (Maugansville, $\mathrm{MD})$ for analysis of $\mathrm{DM}\left(135^{\circ} \mathrm{C}\right.$; AOAC Inernational, 2000; method 930.15$)$, ash $\left(535^{\circ} \mathrm{C}\right.$; AOAC Inernational, 2000; method 942.05), ADF (AOAC Inernational, 2000; method 973.18), NDF with heat-stable $\alpha$-amylase and sodium sulfite (Van Soest et al., 1991), CP $(\mathrm{N} \times 6.25$; AOAC Inernational, 2000; method 990.03; Leco FP528 Nitrogen Analyzer, St. Joseph, MI), and minerals (AOAC Inernational, 2000; method 985.01). Dried refusal samples were analyzed at University of Guelph, Kemptville Campus, using an Ankom ${ }^{2000}$ Fiber Analyzer (Ankom Technology, Macedon, NY) for NDF with heat-stable $\alpha$-amylase and sodium sulfite (Van Soest et al., 1991).

\section{Calculations and Statistical Analysis}

Sorting for each particle fraction of the PSPS was calculated as the actual intake of each fraction expressed as a percentage of the predicted intake of that fraction (Leonardi and Armentano, 2003). The predicted intake of an individual fraction was calculated as the product 
of the group-level DMI of the total diet multiplied by the DM percentage of that fraction in the fed TMR. Values equal to $100 \%$ indicate no sorting, $<100 \%$ indicate selective refusals (sorting against), and $>100 \%$ indicate preferential consumption (sorting for). The physical effectiveness factor (pef) was determined as the DM proportion of particles retained by the top 2 sieves of the PSPS (Yang and Beauchemin, 2006). The physically effective NDF was calculated by multiplying the NDF content of the feed by the pef.

Prior to analyses, data outcomes were screened for normality using the UNIVARIATE procedure of SAS (SAS Institute, 2009). Somatic cell count data were normalized by taking the natural $\log$ of the SCC $(x$ 1,000 cells $/ \mathrm{mL}$ ). Data were summarized by farm and period (summer and winter) to obtain group averages for the outcomes of interest and all possible explanatory variables. Associations between group-average productivity measures (milk yield, milk fat percentage, milk protein percentage, DMI, feed efficiency, and feed sorting) and group-level feeding management and ration characteristics were analyzed with multivariable linear mixed models using the MIXED procedure of SAS (SAS Institute, 2009), treating period as a repeated measure. Farm within period was included in the model as the subject of the repeated statement. The covariance structure used in the repeated statement was compound symmetry, chosen due to best fit according to Schwarz's Bayesian information criterion. All independent variables were screened in univariable models; those variables with $P \leq 0.25$ were retained for the multivariable linear regression modeling (Dohoo et al., 2009). The CORR procedure of SAS was used to determine the level of correlation between the retained explanatory variables. In cases where 2 variables were collinear $(\mathrm{r}>0.6)$, the one with the most biological plausibility was retained for the multivariable model. Multivariable models effects were considered significant at $P<0.05$ and tendencies at $P \leq 0.1$. Manual backward elimination was used to construct the final multivariable models.

\section{RESULTS AND DISCUSSION}

\section{Housing, Environment, and Management}

Average group-level management and cow characteristics are found in Table 1. The average lactating herd size of study farms was 162 , with an average study group size of 83 . Of the 22 farms, $59 \%$ milked twice per day and $41 \%$ milked thrice per day. In the summer period, $45 \%$ of the farms fed once per day and $55 \%$ fed twice per day. In the winter, $50 \%$ fed once per day and $50 \%$ fed twice per day. For those farms feeding twice a day, the interval between feed deliveries ranged from
1 to $12 \mathrm{~h}$. In the summer, $17 \%$ delivered the second feeding within $2 \mathrm{~h}$ after the first, $25 \%$ between 2 and $5 \mathrm{~h}, 25 \%$ between 6 to $9 \mathrm{~h}$, and $33 \%$ greater than $10 \mathrm{~h}$ after the first feed delivery. In the winter period, $27 \%$ delivered the second feeding within $2 \mathrm{~h}$ of the first, $27 \%$ between 2 to $5 \mathrm{~h}, 27 \%$ between 6 to $9 \mathrm{~h}$, and $18 \%$ greater than $10 \mathrm{~h}$ after the first feed delivery. For those farms feeding twice a day, 92 and $82 \%$ mixed 2 separate TMR batches for the feed delivery in summer and winter, respectively. Feed push-up frequency ranged from 0 to 20 times/d, with an average frequency of 4.6 times/d. On average, $36 \%$ of herds pushed-up feed less than 4 times/d and $9 \%$ did not push-up feed. Those herds with no feed push-up had fixed feed bunk designs (i.e., those with retaining walls for holding feed close to the feed barrier; e.g., J-bunk design) that did not require feed push-up.

Average feed bunk space was $0.54 \mathrm{~m} /$ cow, ranging from 0.36 to $0.99 \mathrm{~m} / \mathrm{cow}$. Of the 22 farms, only $18.2 \%$ provided more than the industry recommendation $(0.6$ $\mathrm{m} /$ cow; Grant and Albright, 2001) and 9.1\% provided less than $0.4 \mathrm{~m} / \mathrm{cow}$. Average bunk space reported in this study is higher than that reported by a crosssectional study in Minnesota $(0.46 \mathrm{~m} / \mathrm{cow}$; Endres and Espejo, 2010), but much lower than that reported in Spain (0.69 m/cow; Bach et al., 2008).

Post-and-rail feeder design was most common on farms, with $82 \%$ using this feed bunk design and $18 \%$ using headlocks. Post-and-rail feed barriers provide less of a physical barrier during feeding visits; it is hypothesized that this open design increases successful displacements at the feed bunk. Huzzey et al. (2006) reported favorable decreases in aggressive displacements, especially for subordinate cows, when comparing the use of headlocks to post-and-rail designs.

Average daily barn temperature in summer and winter were 22.2 and $4.5^{\circ} \mathrm{C}$, with a range of 20 to 24.5 and -4.5 to $9.9^{\circ} \mathrm{C}$, respectively. Average barn humidity was $73 \%$ in both summer and winter and ranged from 57.3 to $88.9 \%$ and 48.8 to $88.6 \%$, respectively, in those seasons. Mean environmental temperatures for this geographical region (centered at Kemptville, Canada) were $-4.8 \pm$ $6.1^{\circ} \mathrm{C}$ in the winter and $20.5 \pm 2.9$ and $20.4 \pm 3.7^{\circ} \mathrm{C}$ in the summers of 2011 and 2012, respectively. Average high temperatures were $0.3 \pm 5.9^{\circ} \mathrm{C}$ in the winter and $26.7 \pm 3.5$ and $27.1 \pm 4.4^{\circ} \mathrm{C}$ in the summers of 2011 and 2012 , respectively. Average low temperatures were -9.9 $\pm 7.2^{\circ} \mathrm{C}$ in the winter and $14.2 \pm 3.2$ and $13.7 \pm 3.8^{\circ} \mathrm{C}$ in the summers of 2011 and 2012, respectively.

\section{Ration Characteristics}

Summaries of the ration formulations gathered on farms indicated that farms generally fed a TMR with 
Table 1. Average management and cow characteristics on 22 commercial freestall farms $^{1}$

\begin{tabular}{lccc}
\hline Variable & Mean $\pm \mathrm{SD}$ & Minimum & Maximum \\
\hline Management & & & \\
Lactating herd size (n) $_{\text {Group size }(\mathrm{n})}$ & $161.8 \pm 120$ & 66 & 570 \\
Feed push-up frequency $^{2}$ (n/d) & $83 \pm 32$ & 36 & 176 \\
Bunk space $^{3}(\mathrm{~m} / \mathrm{cow})$ & $4.6 \pm 4$ & 0 & 20 \\
Water space $^{4}(\mathrm{~cm} / \mathrm{cow})$ & $0.54 \pm 0.17$ & 0.36 & 0.99 \\
Stall stocking density $^{5}$ (cows/stall) & $7.2 \pm 2.3$ & 3.8 & 11.7 \\
Refusal rate $^{6}(\%)$ & $1.0 \pm 0.13$ & 0.71 & 1.17 \\
Cow measurements $^{7}$ & $3.5 \pm 2.1$ & 0.87 & 9.3 \\
DIM $^{7}$ & & & 278 \\
Parity $^{7}$ & $187 \pm 47$ & 94 & 4.0 \\
BCS & $2.3 \pm 0.57$ & 1.01 & 3.51 \\
\hline
\end{tabular}

${ }^{1}$ Twenty-two commercial dairy farms were visited for 7 consecutive days in each of summer and winter periods; data were averaged across farm and periods.

${ }^{2}$ Frequency and timing of management practices were recorded daily by the farm manager.

${ }^{3}$ Bunk space was recorded at the start of the first period and calculated daily as group size fluctuated.

${ }^{4}$ Water space was recorded at the start of the first period and calculated daily as group size fluctuated.

${ }^{5}$ Number of stalls in the pen was recorded at the start of the first period; stocking density was calculated daily as group size fluctuated.

${ }^{6}$ Refusal rate $=($ DM refused $/$ DM offered $) \times 100$.

${ }^{7}$ Days in milk and parity were obtained for cows in the focal study group and averaged per herd. Measurements were obtained from the monthly DHI milk test, which occurred within $\pm 3 \mathrm{~d}$ of the 7 -d data collection.

similar base ingredients. Diets typically consisted of a mix of corn silage, alfalfa or grass haylage, high-moisture corn, soybean meal, canola meal, hay, straw, and a protein or mineral supplement mix. During the summer period, $27 \%$ of farms added water to the ration and no farms added water during winter months. A summary of the nutrient concentrations of the analyzed TMR are presented in Table 2. According to NRC (2001) recommendations, the average TMR fed met the requirements for all macronutrients and minerals based on average milk production parameters. However, the greatest variability between farms was evident for CP, NDF, and NFC. Specifically, 4 farms fed higher than the recommended maximum level of NFC during the summer months.

Physical characteristics of the fresh and refusal TMR are described in Table 3. The refused ration was higher in physically effective NDF, pef, and the percentage of long particles and much lower in the percentage of short and fine particles than the average offered ration. Rations in this study generally met some of the recommendations of TMR particle size distribution: between 2 to $8 \%$ long particles, 30 to $50 \%$ medium and short particles, and no more than $20 \%$ fine particles (Heinrichs and Kononoff, 2002). On average, all herds fed rations with less than $20 \%$ fine particles and 91 and $73 \%$ fed rations within the guidelines for short and medium particles, respectively. However, all of the herds fed rations with greater than $8 \%$ long particles and $46 \%$ of herds fed rations with greater than $20 \%$ long particles.

\section{Feed Sorting}

At the group level, cows sorted against the long ration particles (97.3\%), did not sort for or against medium particles (100\%), and sorted for the short and fine ration particles (101\%) during both the summer and winter seasons. Variability between farms was evident, with observed ranges of 88.6 to $100 \%$ for long particles and 99.1 to $103.6 \%$ for fine particles. These findings are congruent with past research in both tiestall- and freestall-grouped cows (Leonardi and Armentano, 2007), indicating that the observed group-housed cows were sorting against consumption of fiber-rich particles and in favor of highly palatable starch-rich particles. The extent of sorting observed by Leonardi and Armentano (2007) in group-housed cows was more extreme than what we observed. This is likely a function of different methodology and tools used by these researchers to calculate sorting, higher refusal rate (6-33\% vs. $3.5 \%)$, and provision of a much drier diet than found in our study (68 vs. 48\% DM; Leonardi and Armentano, 2007). Researchers have found that dry diets (Leonardi et al., 2005; Fish and DeVries, 2012) and feeding for higher refusal rates (Leonardi and Armentano, 2007; Miller-Cushon and DeVries, 2010) promote greater feed-sorting behavior.

Reduced sorting against long ration particles was associated with feeding for lower refusal rates and tended to be associated with increased feeding frequency (twice vs. once per day; Table 4). On average, herds feeding twice per day compared with once per day tended to 
Table 2. Average nutrient composition of the TMR delivered on 22 commercial freestall farms ${ }^{1,2}$

\begin{tabular}{lccc}
\hline $\begin{array}{l}\text { Variable } \\
\text { (\% of DM, } \\
\text { unless otherwise noted) }\end{array}$ & & & \\
\hline $\mathrm{CP}$ & Mean $\pm \mathrm{SD}$ & Minimum & Maximum \\
$\mathrm{NDF}$ & $16.5 \pm 0.85$ & 14.0 & 18.2 \\
$\mathrm{ADF}$ & $31.3 \pm 1.90$ & 26.0 & 34.9 \\
$\mathrm{Ash}$ & $20.5 \pm 1.17$ & 17.7 & 21.9 \\
$\mathrm{TDN}$ & $7.9 \pm 0.41$ & 6.8 & 8.3 \\
$\mathrm{NE}(\mathrm{Mcal} / \mathrm{kg})$ & $73.5 \pm 1.10$ & 71.8 & 75.3 \\
$\mathrm{NFC}$ & $1.70 \pm 0.03$ & 1.66 & 1.75 \\
$\mathrm{Ca}$ & $41.2 \pm 2.11$ & 37.6 & 46.8 \\
$\mathrm{P}$ & $0.92 \pm 0.12$ & 0.70 & 0.19 \\
$\mathrm{Mg}$ & $0.42 \pm 0.03$ & 0.35 & 0.38 \\
$\mathrm{~K}$ & $0.35 \pm 0.05$ & 0.26 & 1.85 \\
$\mathrm{Na}$ & $1.45 \pm 0.15$ & 1.18 & 0.62 \\
$\mathrm{Fe}(\mathrm{mg} / \mathrm{kg})$ & $0.41 \pm 0.09$ & 0.22 & 553 \\
$\mathrm{Mn}(\mathrm{mg} / \mathrm{kg})$ & $324 \pm 83$ & 229 & 107 \\
$\mathrm{Zn}(\mathrm{mg} / \mathrm{kg})$ & $72.2 \pm 12.9$ & 50.6 & 126.4 \\
$\mathrm{Cu}(\mathrm{mg} / \mathrm{kg})$ & $90.7 \pm 14.2$ & 67.6 & 31.5 \\
\hline
\end{tabular}

${ }^{1}$ Twenty-two commercial dairy farms were visited for 7 consecutive days in each of summer and winter periods; data were averaged across each farm and periods.

${ }^{2}$ Fresh TMR samples were collected daily for 7 consecutive days in each period; data were averaged across period.

experience a 0.86 -percentage-point decrease in sorting against long particles at a group-level. The implications of this association are hard to interpret, as the results are on a group-level and it is impossible to determine individual cow sorting values for group-housed cows. However, Leonardi and Armentano (2007) reported that the extent of feed sorting is greater in a group setting compared with a tiestall setting; thus, potentially becoming more meaningful at the individual cow level. More importantly, our results showed that every 2 point increase in selective refusal (i.e., sorting against) of long particles on a group level was associated with a per cow reduction of $0.9 \mathrm{~kg} / \mathrm{d}$ of $4 \% \mathrm{FCM}(P=0.036)$. The effect of frequent delivery of fresh feed on reduced feed sorting, on the basis of less change in NDF content in the TMR over the course of the day, has been previously documented (DeVries et al., 2005; Endres and Espejo, 2010). Our study is the first to suggest that increased frequency of feed delivery to group-housed cows may beneficially reduce feed sorting at the particle level, thus promoting intake of a ration with the intended particle size distribution to maintain optimal rumen health and productivity.

More sorting in favor of short and fine particles was associated with higher refusal rates (Table 4). In contrast, Miller-Cushon and DeVries (2010) found a negative correlation between feeding amount and sorting against short particles. However, sorting patterns ex-

Table 3. Particle size distribution and characteristics of TMR offered and refused on 22 commercial freestall farms ${ }^{1}$

\begin{tabular}{lcc}
\hline $\begin{array}{l}\text { Variable } \\
\text { (\%, unless otherwise noted) }\end{array}$ & $\begin{array}{c}\text { Offered ration } \\
(\text { mean } \pm \mathrm{SD})\end{array}$ & $\begin{array}{c}\text { Refused ration } \\
(\text { mean } \pm \mathrm{SD})\end{array}$ \\
\hline DM & $47.7 \pm 2.8$ & $46.1 \pm 3.0$ \\
Particle size & & \\
$\quad$ Long & $19.8 \pm 6.5$ & $33.1 \pm 9.5$ \\
Medium & $34.3 \pm 6.6$ & $35.0 \pm 7.2$ \\
Short & $35.5 \pm 4.3$ & $24.8 \pm 5.2$ \\
Fine & $10.5 \pm 2.9$ & $6.6 \pm 1.4$ \\
pef $^{3}$ & $54.1 \pm 5.0$ & $68.2 \pm 6.0$ \\
peNDF $^{4}(\%$ of DM) & $17.0 \pm 2.1$ & $24.5 \pm 3.6$ \\
\hline
\end{tabular}

${ }^{1}$ Twenty-two commercial dairy farms were visited for 7 consecutive days in each of summer and winter periods; data were averaged across farm and periods.

${ }^{2}$ Particle size was measured using a Penn State Particle Separator that divided the sample into 4 fractions: long $(>19 \mathrm{~mm})$, medium $(<19$ and $>8 \mathrm{~mm})$, short $(<8$ and $>1.18 \mathrm{~mm})$, and fine $(<1.18 \mathrm{~mm})$.

${ }^{3}$ pef $=$ physical effectiveness factor measured as the sum of the DM proportions retained on the top 2 Penn State Particle Separator sieves.

${ }^{4}$ peNDF $=$ physically effective NDF measured by multiplying pef by the NDF (\% of DM) content of the ration. 
Table 4. Final group-level multivariable linear regression models for factors associated with sorting ${ }^{1}$ of TMR particle fractions $^{2}$

\begin{tabular}{|c|c|c|c|c|c|c|c|c|c|c|c|c|}
\hline Variable & \multicolumn{3}{|c|}{ Long particle sorting (\%) } & \multicolumn{3}{|c|}{ Medium particle sorting (\%) } & \multicolumn{3}{|c|}{ Short particle sorting (\%) } & \multicolumn{3}{|c|}{ Fine particle sorting (\%) } \\
\hline Intercept & 99.2 & 0.55 & $<0.001$ & 101.8 & 3.8 & $<0.001$ & 102.6 & 1.25 & $<0.001$ & 99.3 & 0.36 & $<0.001$ \\
\hline Period & & & & & & & & & & & & 0.004 \\
\hline Winter & - & - & - & - & - & - & - & - & - & $\operatorname{Ref}^{4}$ & & \\
\hline Summer & - & - & - & - & - & - & - & - & - & -0.57 & 0.19 & \\
\hline Feeding frequency (no./d) & & & 0.095 & & & & & & & & & \\
\hline 1 & $\operatorname{Ref}^{4}$ & - & - & - & - & - & - & - & - & - & - & - \\
\hline 2 & 0.86 & 0.50 & - & - & - & - & - & - & - & - & - & - \\
\hline Refusal rate ${ }^{5}$ & -0.65 & 0.11 & $<0.001$ & - & - & - & 0.29 & 0.03 & $<0.001$ & 0.25 & 0.04 & $<0.001$ \\
\hline Short particles & - & - & - & -0.04 & 0.017 & 0.014 & - & - & - & - & - & - \\
\hline Fine particles & - & - & - & -0.1 & 0.02 & $<0.001$ & - & - & - & 0.1 & 0.03 & $<0.001$ \\
\hline
\end{tabular}

${ }^{1}$ Sorting $=100 \times($ fraction DMI/ predicted fraction DMI), where fraction $=$ long, medium, short, or fine particles. Sorting values equal to $100 \%$ indicate no sorting, $<100 \%$ indicate selective refusal (sorting against), and $>100 \%$ indicate preferential consumption (sorting for). Data were collected on 22 commercial dairy farms for 7 consecutive days during winter and summer periods.

${ }^{2}$ Particle size determined by Penn State Particle Separator, which has a 19-mm screen (long), 8-mm screen (medium), 1.18-mm screen (short), and a pan (fine).

${ }^{3} \beta=$ estimated regression coefficient.

${ }^{4}$ Ref $=$ reference category.

${ }^{5}$ Refusal rate $=($ DM refused $/ \mathrm{DM}$ offered $) \times 100 \%$.

hibited in that study were not typical, as cows sorted to a greater extent against shorter particles than long particles (Miller-Cushon and DeVries, 2010). Our results demonstrated that every 2-percentage-point increase in refusal rate was associated with a $1.3 \%$ increase in group-level selective refusal of long particles and 0.6 and $0.5 \%$ increases in group-level selective consumption of short and fine particles, respectively. The average refusal rates in our study are much lower $(3.5 \%$, range $=0-10.3 \%)$ than those reported in previous controlled studies (6-33\%; Leonardi and Armentano, 2007; 11.4 and 18\%; Miller-Cushon and DeVries, 2010), but are more representative of commercial feeding. Overall, herds were feeding for low feed wastage, with $32 \%$ of herds feeding for less than $2 \%$ refusal and $73 \%$ feeding for less than $5 \%$ refusal. The results of this study suggest that feeding for a low refusal amount may not only have economic benefits associated with reduced feed wastage, but may also promote consumption of a diet closer to that intended. To date, no seasonal effects on feed sorting patterns have been studied. Interestingly, cows exhibited more preference for fine particles in the winter compared with summer, with group-level sorting being 0.57 percentage points lower on average in summer months (Table 4). Once again, the implications of this finding are impossible to interpret at an individual level. This observation may be partially explained by the higher proportion of herds delivering feed twice per day in summer compared with winter. The current study, as well as past research, suggests that an increased frequency of feeding reduces the extent of feed sorting (DeVries et al., 2005; Endres and Espejo, 2010).

An increased proportion of fine particles in TMR was associated with more sorting in favor of fine particles and less sorting for medium particles (Table 4). Provision of a diet that is proportionally higher in long particles will increase sorting in favor of short particles (Leonardi and Armentano, 2003), whereas a provision of a diet proportionally higher in short particles increases the extent of sorting for those shorter particles (DeVries et al., 2007). The rationale is that formulation of a diet with easily distinguished particle fractions (i.e., increased proportion of long or fine particles) increases the ease with which cows can easily select those highly desired smaller particles.

\section{DMI}

Average DMI was similar across seasons and is presented in Table 5. Controlling for the effects of DIM, parity and milking frequency, increased frequency of feed delivery (twice vs. once per day) was associated with a $1.42 \mathrm{~kg} / \mathrm{d}$ increase per cow in DMI (Table 6). Other reports on the effect of frequency of feed delivery on feed intake of group-housed cows are inconsistent. Increasing feeding frequency of heifers improved aver- 
age daily gain and efficiency of feed utilization, potentially as a result of increased feed intake (Gibson, 1981). Increased frequency of delivery of fresh feed had no effect on feed intake of tiestall-housed cows (Alzahal et al., 2006) and group-housed cows (Phillips and Rind, 2001). However, DeVries et al. (2005) reported favorable increases in daily feeding time and more equal distribution of feeding events throughout the day as a result of delivering feed twice versus once per day. This has favorable implications for rumen health, as consumption of smaller, more frequent meals is thought to reduce the risk of subacute ruminal acidosis (Krause and Oetzel, 2006). Along those same lines, increased frequency of feed delivery reduces the magnitude of postprandial decline in rumen $\mathrm{pH}$, thus contributing to increased ruminal health (French and Kennelly, 1990). Reduced diurnal fluctuations in rumen $\mathrm{pH}$ may translate to improved fiber digestibility (Mertens, 1997), which in turn may increase rate of passage and result in greater DMI.

\section{Milk Production Parameters}

Test-day milk yield, FCM, and ECM are found in Table 5. Factors associated with test-day milk yield are presented in Table 7. A positive association between increased frequency of feed delivery and milk yield was found, with twice per day feed delivery being associated with $2.01 \mathrm{~kg} / \mathrm{d}$ greater yield per cow. Though it is unknown if this relationship is causal, this finding is not surprising as increased frequency of feed delivery was also associated with increased DMI (Table 6), which is a major determinant of milk yield (Dado and Allen, 1994). Additionally, reduced sorting against long particles at a group level was associated with increased $4 \%$ FCM and ECM. It could be hypothesized that less sorting would result in reduced variability in rumen $\mathrm{pH}$ (DeVries et al., 2008) as well as increased fiber intake and digestibility (Mertens, 1997), thus contributing to improved diet digestibility to promote increased milk production.

Providing cows with greater water trough space tended to be associated with greater test-day milk yield (Table 7), as well as greater FCM and ECM. We found that milk yield tended to increase by $0.77 \mathrm{~kg} / \mathrm{d}$ for every $2 \mathrm{~cm} /$ cow increase in water trough space; the range of observed water trough space was 3.8 to 11.7 $\mathrm{cm} /$ cow. Water is perhaps the most necessary nutrient (NRC, 2001). This result illustrates the importance of water availability for group-housed cows and suggests that resource availability greatly affects potential productivity.

Average group-level efficiency of milk production was $1.41 \mathrm{~kg}$ of milk/kg of DMI (Table 5 ). Greater efficiency of milk yield, FCM, and ECM was associated with milking cows of lower DIM and milking more frequently (thrice vs. twice per day; Table 5). This is consistent with past findings that efficiency typically increases as DIM decreases (Britt et al., 2003) and as milking frequency increases (Barnes et al., 1990). Milk-

Table 5. Average productivity measures of dairy cows on 22 commercial freestall farms ${ }^{1}$

\begin{tabular}{|c|c|c|c|}
\hline Item & Mean \pm SD & Minimum & Maximum \\
\hline $\mathrm{DMI}^{2}(\mathrm{~kg} / \mathrm{d})$ & $24.3 \pm 2.1$ & 20.9 & 28.7 \\
\hline \multicolumn{4}{|l|}{ Milk yield $(\mathrm{kg} / \mathrm{d})$} \\
\hline Milk ${ }^{3}$ & $34.3 \pm 5.9$ & 24.6 & 46.3 \\
\hline $4 \% \mathrm{FCM}$ & $33.2 \pm 5.2$ & 24.3 & 46.8 \\
\hline $\mathrm{ECM}$ & $35.6 \pm 5.4$ & 26.7 & 48.4 \\
\hline \multicolumn{4}{|l|}{ Milk composition $^{3}(\%)$} \\
\hline Fat & $3.75 \pm 0.23$ & 3.17 & 4.14 \\
\hline Protein & $3.24 \pm 0.15$ & 2.96 & 3.51 \\
\hline \multicolumn{4}{|l|}{ Milk component yield ${ }^{3}(\mathrm{~kg} / \mathrm{d})$} \\
\hline Fat & $1.27 \pm 0.18$ & 0.98 & 1.66 \\
\hline Protein & $1.10 \pm 0.17$ & 0.82 & 1.43 \\
\hline \multicolumn{4}{|c|}{ Efficiency of milk production ${ }^{4}(\mathrm{~g} / \mathrm{kg})$} \\
\hline Milk/DMI & $1.41 \pm 0.16$ & 1.15 & 1.69 \\
\hline $4 \% \mathrm{FCM} / \mathrm{DMI}$ & $1.36 \pm 0.13$ & 1.12 & 1.61 \\
\hline ECM/DMI & $1.46 \pm 0.13$ & 1.22 & 1.71 \\
\hline $\operatorname{MUN}^{3}(\mathrm{mg} / \mathrm{dL})$ & $10.49 \pm 1.89$ & 6.08 & 13.68 \\
\hline $\mathrm{SCC}^{3}(\mathrm{SCC} \times 1,000$ cells $/ \mathrm{mL})$ & $225 \pm 129$ & 93 & 600 \\
\hline
\end{tabular}

${ }^{1}$ Twenty-two commercial dairy farms were visited for 7 consecutive days in each of summer and winter periods; data were averaged across farm and periods.

${ }^{2}$ Dry matter intake was calculated daily by subtracting the pen-level DM refused from DM offered and dividing by the number of cows.

${ }^{3}$ Milk production parameters were obtained from a coinciding DHI test ( $\pm 3 \mathrm{~d}$ of data collection period) for cows in the focal group and averaged for group and period (summer and winter).

${ }^{4}$ Efficiency of milk production calculated by dividing milk yield by average DMI of focal cows. 
Table 6. Final multivariable linear regression models for factors associated with DMI, MUN, and SCC ${ }^{1}$

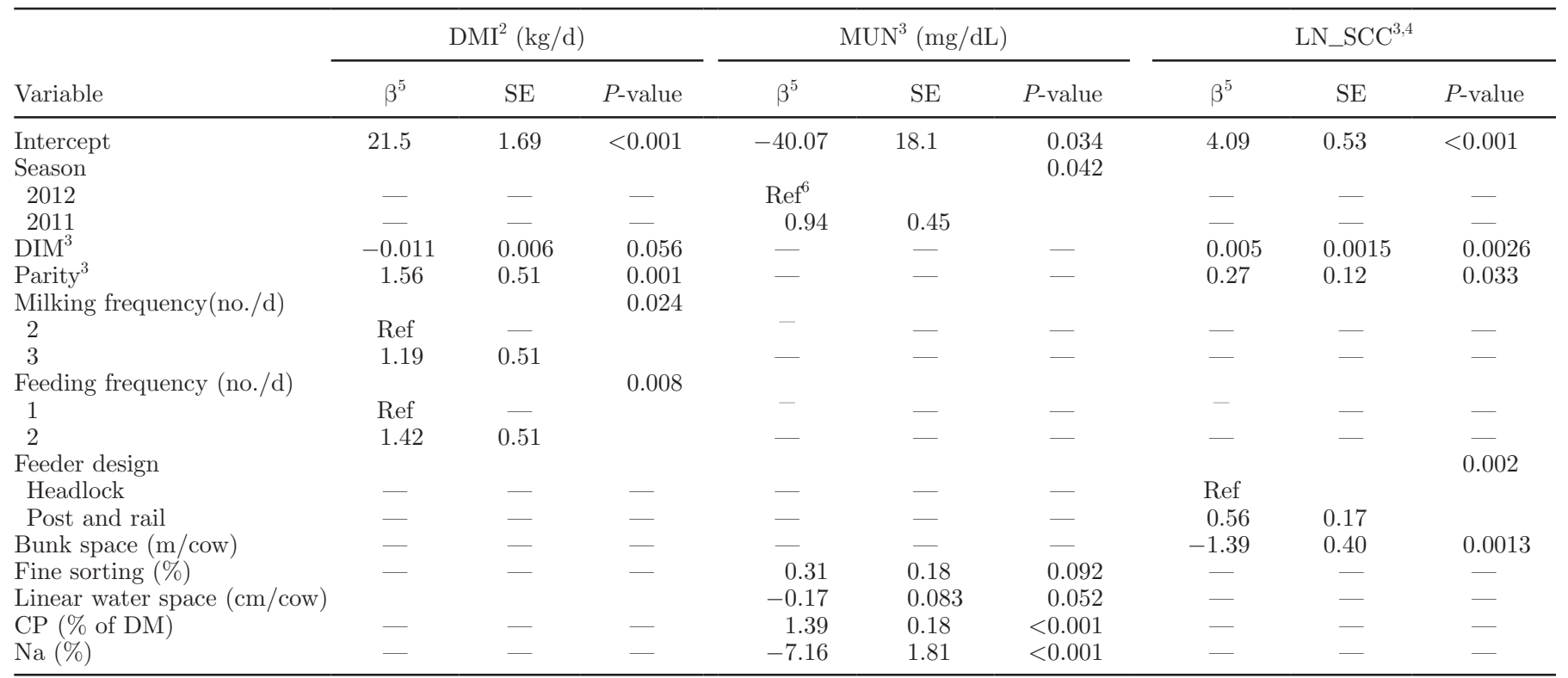

${ }^{1}$ Data were collected on 22 commercial dairy farms for 7 consecutive days during winter and summer periods.

${ }^{2}$ DMI was calculated daily by subtracting the DM refused from DM offered; averaged over $7 \mathrm{~d}$.

${ }^{3}$ Milk production parameters collected from a coinciding DHI test ( $\pm 3 \mathrm{~d}$ of data collection period).

${ }^{4} \mathrm{LN} \_\mathrm{SCC}=$ natural $\log$ of $\mathrm{SCC}(\times 1,000$ cells $/ \mathrm{mL})$.

${ }^{5} \beta=$ estimated regression coefficient.

${ }^{6} \operatorname{Ref}=$ reference category.

ing thrice per day compared with twice per day was associated with an $11.6 \%$ increase in efficiency of milk production. Increased efficiency of test-day milk yield was associated with less sorting for fine particles (Table 7); efficiency of milk production decreased by $3 \%$ for every $1 \%$ of group-level selective consumption (sorting) of fine particles. Excessive sorting in favor of consuming rapidly digestible short particle components is a risk factor for depressed rumen $\mathrm{pH}$ (DeVries et al., 2008), potentially reducing the efficiency of nutrient utilization.

Providing cows with more space at the feed bunk was associated with improved milk fat percentage (Table 8). Every $10 \mathrm{~cm} /$ cow increase in bunk space was associated

Table 7. Final multivariable linear regression models for factors associated with milk yield and efficiency of milk production ${ }^{1}$

\begin{tabular}{|c|c|c|c|c|c|c|}
\hline \multirow[b]{2}{*}{ Variable } & \multicolumn{3}{|c|}{ Test day milk yield ${ }^{2}(\mathrm{~kg} / \mathrm{d})$} & \multicolumn{3}{|c|}{$\begin{array}{l}\text { Efficiency of test day milk yield }{ }^{2} \\
\quad(\mathrm{~kg} \text { of milk/kg of DMI })\end{array}$} \\
\hline & $\beta^{3}$ & $\mathrm{SE}$ & $P$-value & $\beta^{3}$ & $\mathrm{SE}$ & $P$-value \\
\hline DIM & -0.06 & 0.01 & $<0.001$ & -0.002 & 0.0004 & $<0.001$ \\
\hline Parity & 3.09 & 0.84 & $<0.001$ & - & - & - \\
\hline Milking frequency (no./d) & & & $<0.001$ & & & $<0.001$ \\
\hline 1 & Ref & - & & - & - & - \\
\hline 2 & 2.01 & 0.98 & & - & - & - \\
\hline Fine particle sorting ${ }^{5}(\%)$ & - & - & - & -0.046 & 0.018 & 0.014 \\
\hline Linear water space $(\mathrm{cm} / \mathrm{cow})$ & 0.384 & 0.22 & 0.081 & - & - & - \\
\hline
\end{tabular}

${ }^{1}$ Data were collected on 22 commercial dairy farms for 7 consecutive days during winter and summer periods.

${ }^{2}$ Milk production parameters collected from a coinciding DHI test ( $\pm 3 \mathrm{~d}$ of data collection period).

${ }^{3} \beta=$ estimated regression coefficient.

${ }^{4}$ Ref $=$ reference category.

${ }^{5}$ Fine particle sorting $=$ predicted intake/actual intake of TMR particles $<1.18 \mathrm{~mm}$ in length. 
with a 0.06 -percentage-point increase in milk fat percentage. This finding is congruent with our hypothesis that improvements in feed access translate to improvements in herd-level production parameters. Research has shown that providing more feed bunk space results in more consistent feeding patterns throughout the day (i.e., smaller, more frequent meals throughout the day), whereas decreased feed bunk space increases the rate of consumption and average meal size (Hosseinkhani et al., 2008). Rapid consumption of larger meals increases the risk of ruminal acidosis (Krause and Oetzel, 2006), as the rate of $\mathrm{pH}$ decline postfeeding is related to the size of meal consumed (Allen, 1997). Thus, cows with increased bunk space should consume smaller, more frequent meals throughout the day and experience less severe postprandial drops in rumen $\mathrm{pH}$, and therefore be able to synthesize more milk fat (Bauman and Griinari, 2003) Additionally, reduced group-level sorting against the consumption of long particles was associated with greater milk fat yield $(P=0.052)$ but not milk fat percentage. Reduced sorting against long particles results in increased intake of fiber and increased rumen pH (DeVries et al., 2008), thus contributing to optimal rumen conditions for milk fat synthesis.

Group-average milk protein was $3.24 \%$ (Table 5) and was associated with a 0.15 -percentage-point decrease during summer months (Table 8). Increased milking frequency (thrice vs. twice per day) was associated with reduced milk protein percentage (Table 8 ), but did not affect total protein yield. Every $2 \mathrm{~cm} / \mathrm{cow}$ increase in water space was associated with a 0.05-percentagepoint decrease in milk protein percentage (Table 8). This result may be a result of our finding that increased water trough space was associated with increased milk yield. Milk protein yield was unaffected by water trough space, thus milk protein percentage was reduced.

Group average SCC was 225,000 SCC/mL and varied greatly between farms (Table 5). Farms with post and rail feed barrier, compared with headlocks, had higher SCC (Table 6); on average, using a headlock feed barrier was associated with a $43 \%$ decrease in group-average SCC. It is unknown whether unmeasured variables had any effect on this finding; however, the effect of using headlocks on competition at the feed bunk may help explain this association. Headlock feed barriers result in an increase in feeding success at the bunk, evidenced by a reduction in aggressive displacement from the feed bunk (Huzzey et al., 2006). Additionally, increased group-average SCC was associated with reduced feed bunk space (Table 6 ). It could be hypothesized in situations with reduced feed bunk space and reduced success at the feed bunk that some cows may choose to lie down sooner following exit from the milking parlor to avoid social interactions; this decreased postmilking standing time may potentially increase the risk of IMI (DeVries et al., 2010). Postmilking standing time is greatly influenced by management factors, such as the delivery of fresh feed (DeVries et al., 2010); thus, presenting producers with a means of reducing risk of IMI and increasing udder health.

Milk urea nitrogen is an indicator of protein metabolism and can be used to monitor CP utilization of the ration (Biswajit et al., 2011). Not surprisingly, higher MUN was associated with increased $\mathrm{CP}$ in the ration (Table 6), as provision of $\mathrm{CP}$ in excess of requirements results in nitrogen excretion (Biswajit et al., 2011). We found that every $1 \%$ increase in ration $\mathrm{CP}$ was associated with a $12.6 \%$ increase in MUN, indicating excess

Table 8. Final multivariable linear regression models for factors associated with milk fat and protein ${ }^{1}$

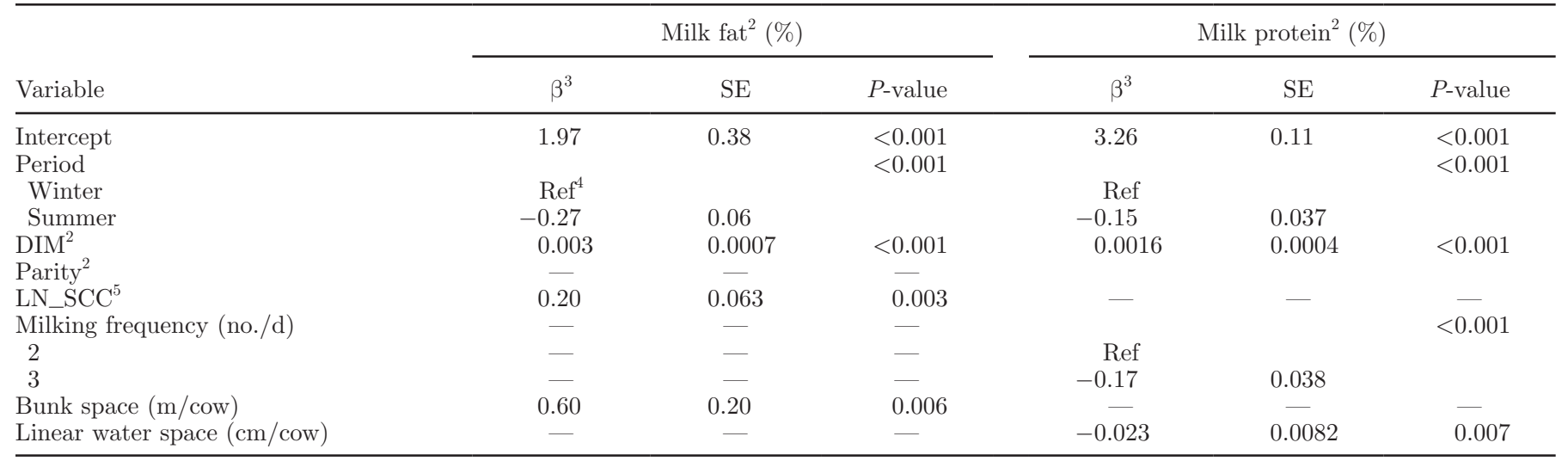

${ }^{1}$ Data were collected on 22 commercial dairy farms for 7 consecutive days during each winter and summer period.

${ }^{2}$ Milk production parameters collected from a coinciding DHI test ( $\pm 3 \mathrm{~d}$ of data collection period).

${ }^{3} \beta=$ estimated regression coefficient.

${ }^{4}$ Ref $=$ reference category.

${ }^{5} \mathrm{LN} \_\mathrm{SCC}=$ natural $\log$ of SCC $(\times 1,000$ cells $/ \mathrm{mL})$. 
nitrogen excretion. Increased sorting for fine particles and reduced water trough space also tended to be associated with increased MUN (Table 6). Specifically, every $2 \mathrm{~cm} /$ cow increase in water trough space was associated with a $3 \%$ reduction in MUN and every $1 \%$ increase in group-level sorting for fine particles was associated with a $2.8 \%$ increase in MUN.

\section{CONCLUSIONS}

The results of this observational study indicate that feeding management practices to promote feed and bunk access are associated with group-average productivity. It was found that herds fed twice per day versus once per day had greater DMI and milk yield and exhibited less sorting against long ration particles. Additionally, providing cows with more space at the feed bunk was associated with lower group-average SCC and higher milk fat percentage. It must be noted that the results presented in this study are based on group-level averages, thus making it impossible to interpret the conclusions on an individual cow basis. Nevertheless, this field study corroborates many of the findings presented by previous controlled trials investigating the effects of feeding, management, and housing on sorting and productivity measures of group-housed dairy cows. Studies of this nature allow a broadened understanding of the associations discovered in controlled studies while simultaneously generating questions for future research.

\section{ACKNOWLEDGMENTS}

We thank the participating producers for use of their facilities. We also thank CanWest DHI (Guelph, Canada) for their cooperation and for facilitating producer enrollment in the study. We thank technical staff and students at the University of Guelph, Kemptville Campus, for their role in data collection and processing: Megan Bruce, Alexa Main, Nancy Stonos, John Wynands and Morgan Overvest. Dairy Farmers of Canada (Ottawa, Canada), the Canadian Dairy Commission (Ottawa, Canada), and Agriculture and Agri-Food Canada (Ottawa, Canada) provided financial support for this study. Additional project support was received from the Ontario Ministry of Agriculture, Food and Rural Affairs (Guelph, Canada), the Canadian Foundation for Innovation (Ottawa, Canada), and the Ontario Research Fund (Toronto, Canada).

\section{REFERENCES}

Allen, M. S. 1997. Relationship between fermentation acid production in the rumen and the requirement for physically effective fiber. J. Dairy Sci. 80:1447-1462.
Alzahal, H., J. L. Benford, T. Widowski, J. P. Walton, J. C. Plazier, T. Duffield, N. E. Odongo, and B. W. McBride. 2006. Effects of frequency of feed delivery on dairy cattle behavior. Prof. Anim. Sci. $22: 80-83$.

AOAC International. 2000. Official Methods of Analysis. Vol. I. 17th ed. AOAC International, Arlington, VA.

Bach, A., N. Valls, A. Solans, and T. Torrent. 2008. Associations between nondietary factors and dairy herd performance. J. Dairy Sci. 91:3259-3267.

Barnes, M. A., R. E. Pearson, and A. J. Lukes-Wilson. 1990. Effects of milking frequency and selection for milk yield on productive efficiency of Holstein cows. J. Dairy Sci. 1990:1603-1611.

Bauman, D. E., and J. M. Griinari. 2003. Nutritional regulation of milk fat synthesis. Annu. Rev. Nutr. 23:203-227.

Biswajit, R., B. Brahma, S. Ghosh, P. K. Pankaj, and G. Mandal. 2011. Evaluation of milk urea concentration as a useful indicator for dairy herd management: A review. Asian J. Anim. Vet. Adv. $6: 1-19$.

Britt, J. S., R. C. Thomas, N. C. Speer, and M. B. Hall. 2003. Efficiency of converting nutrient dry matter to milk in Holstein herds. J. Dairy Sci. 86:3796-3801.

Coppock, C. E., D. L. Bath, and B. Harris Jr. 1981. From feeding to feeding systems. J. Dairy Sci. 64:1230-1249.

Dado, R. G., and M. S. Allen. 1994. Variation in and relationships among feeding, chewing, and drinking variables for lactating dairy cows. J. Dairy Sci. 77:132-144.

DeVries, T. J., K. A. Beauchemin, and M. A. G. von Keyserlingk. 2007. Dietary forage concentration affects the feed sorting behaviour of lactating dairy cows. J. Dairy Sci. 90:5572-5579.

DeVries, T. J., F. Dohme, and K. A. Beauchemin. 2008. Repeated ruminal acidosis challenges in lactating dairy cows at high and low risk for developing acidosis: Feed sorting. J. Dairy Sci. 91:39583967.

DeVries, T. J., S. Dufour, and D. T. Scholl. 2010. Relationship between feeding strategy, lying behavior patterns, and incidence of intramammary infection in dairy cows. J. Dairy Sci. 93:1987-1997.

DeVries, T. J., and M. A. G. von Keyserlingk. 2005. Time of feed delivery affects the feeding and lying patterns of dairy cows. J. Dairy Sci. 88:625-631.

DeVries, T. J., M. A. G. von Keyserlingk, and K. A. Beauchemin. 2003. Diurnal feeding pattern of lactating dairy cows. J. Dairy Sci. 86:4079-4082.

DeVries, T. J., M. A. G. von Keyserlingk, and K. A. Beauchemin. 2005. Frequency of feed delivery affects the behavior of lactating dairy cows. J. Dairy Sci. 88:3553-3562.

Dohoo, I., W. Martin, and H. Stryhn. 2009. Veterinary Epidemiologic Research. 2nd ed. VER Inc., Charlottetown, PEI, Canada.

Endres, M. I., and L. A. Espejo. 2010. Feeding management and characteristics of rations for high-producing dairy cows in freestall herds. J. Dairy Sci. 93:822-829.

Fish, J. A., and T. J. DeVries. 2012. Varying dietary dry matter concentration through water addition: Effect on nutrient intake and sorting of dairy cows in late lactation. J. Dairy Sci. 95:850-855.

French, N., and J. J. Kennelly. 1990. Effects of feeding frequency on ruminal parameters, plasma insulin, milk yield, and milk composition in Holstein cows. J. Dairy Sci. 73:1857-1863.

Gibson, J. P. 1981. The effects of feeding frequency on the growth and efficiency of food utilization of ruminants: An analysis of published results. Anim. Prod. 32:275-283.

Grant, R. J., and J. L. Albright. 2001. Effect of animal grouping on feeding behavior and intake of dairy cattle. J. Dairy Sci. 84:E156E163.

Heinrichs, J., and P. Kononoff. 2002. Evaluating Particle Size of Forages and TMRs using the New Penn State Forage Particle Separator. Accessed Dec. 12, 2012. http://www.vetmed.wsu.edu/coursesjmgay/documents/DAS02421.pdf.

Hintze, J. 2008. PASS 2008. NCSS LLC, Kaysville, UT. www.ncss. com.

Hosseinkhani, A., T. J. DeVries, K. L. Proudfoot, R. Valizadeh, D. M. Veira, and M. A. G. von Keyserlingk. 2008. The effects of feed 
bunk competition on the feed sorting behavior of close-up dry cows. J. Dairy Sci. 91:1115-1121.

Huzzey, J. M., T. J. DeVries, P. Valois, and M. A. G. von Keyserlingk. 2006. Stocking density and feed barrier design affect the feeding and social behavior of dairy cattle. J. Dairy Sci. 89:126-133.

Kononoff, P. J., A. J. Heinrichs, and D. R. Buckmaster. 2003. Modification of Penn State forage and total mixed ration particle separator and the effects of moisture content on its measurements. J. Dairy Sci. 86:1858-1863.

Krause, K. M., and G. R. Oetzel. 2006. Understanding and preventing subacute ruminal acidosis in dairy herds: A review. Anim. Feed Sci. Technol. 126:215-236.

Leonardi, C., and L. E. Armentano. 2003. Effect of quantity, quality, and length of alfalfa hay on selective consumption by dairy cows. J. Dairy Sci. 86:557-564.

Leonardi, C., and L. E. Armentano. 2007. Feed selection by dairy cows fed individually in a tie-stall or as a group in a free-stall barn. J. Dairy Sci. 90:2386-2389.

Leonardi, C., F. Giannico, and L. E. Armentano. 2005. Effect of water addition on selective consumption (sorting) of dry diets by dairy cattle. J. Dairy Sci. 88:1043-1049.

Mertens, D. R. 1997. Creating a system for meeting the fiber requirements of dairy cows. J. Dairy Sci. 80:1463-1481.

Miller-Cushon, E. K., and T. J. DeVries. 2010. Feeding amount affects the sorting behavior of lactating dairy cows. Can. J. Anim. Sci. $90: 1-7$.
NRC. 2001. Nutrient Requirements of Dairy Cattle. 7th rev. ed. National Academic Press, Washington, DC.

Phillips, C. J. C., and M. I. Rind. 2001. The effects of frequency of feeding a total mixed ration on the production and behavior of dairy cows. J. Dairy Sci. 84:1979-1987.

SAS Institute. 2009. SAS User's Guide. Version 9.2. SAS Institute Inc., Cary, NC.

Tyrrell, H. F., and J. T. Reid. 1965. Calculating the energy content of cow's milk. J. Dairy Sci. 40:1265-1269.

USDA-ERS. 2013. Monthly cost of production estimates. USDA-Economic Research Service, Washington, DC. Accessed Mar. 9, 2013. http://www.ers.usda.gov/data-products/milk-cost-of-productionestimates.aspx.

Van Soest, P. J., J. B. Robertson, and B. A. Lewis. 1991. Methods for dietary fiber, neutral detergent fiber and nonstarch polysaccharide in relation to animal nutrition. J. Dairy Sci. 74:3583-3597.

Wildman, E. E., G. M. Jones, P. E. Wagner, R. L. Boman, H. F. Troutt, and T. N. Lesch. 1982. A dairy cow body condition scoring system and its relationship to selected production characteristics. J. Dairy Sci. 65:495-501.

Yang, W. Z., and K. A. Beauchemin. 2006. Increasing the physically effective fiber content of dairy cow diets may lower efficiency of feed use. J. Dairy Sci. 89:2694-2704. 